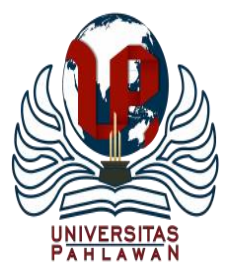

Edukatif : Jurnal Ilmu Pendidikan Volume 3 Nomor 4 Tahun 2021 Halm 1907 - 1914

EDUKATIF: JURNAL ILMU PENDIDIKAN

Research \& Learning in Education

https://edukatif.org/index.php/edukatif/index

\title{
Pengaruh Model Discovery Learning dan Kemandirian Belajar terhadap Hasil Belajar Siswa di Sekolah Dasar
}

\author{
Rohmatul Fithriyah $^{1 凶}$, Satrio Wibowo ${ }^{2}$, Rosyidah Umami Octavia ${ }^{3}$ \\ Pendidikan Guru Sekolah Dasar, STKIP PGRI Sidoarjo, Indonesia ${ }^{1,2,3}$ \\ E-mail : rohmatulfitri42@gmail.com ${ }^{1}, \underline{\text { sejarahsatrio@gmail.com }}^{2}, \underline{\text { rosyidahumami2510@gmail.com }}^{3}$
}

\begin{abstract}
Abstrak
Tujuan penelitian ini dilakukan adalah untuk mengetahui tentang pengaruh dari model discovery learning dan kemandirian belajar terhadap hasil belajar siswa khususnya kelas 4 SDN Ganting. Pada penelitian ini digunakan sarana penelitian berupa lembar observasi dan angket yang diberikan kepada siswa kelas 4 SDN Ganting yang berjumlah secara keseluruhan adalah 41 siswa atau responden. Pelaksanaan penelitian dilakukan secara online dengan alasan pandemi COVID-19. Hasil dari penelitian yang berjenis kuantitatif ini memperoleh nilai simultan sebanyak 36,227 yang didapatkan memalui uji F ANOVA. Dapat ditarik kesimpulan bahwa model discovery learning dan kemandirian belajar mempunyai pengaruh pada hasil belajar siswa.
\end{abstract}

Kata Kunci: Model Discovery Learning, Kemandirian Belajar, Hasil Belajar Siswa.

\section{Abstract}

The purpose of this research was to find out about the effect of the discovery learning model and independent learning on student learning outcomes, especially in the 4th-grade of SDN Ganting. This research, used instrument form of observation sheets and questionnaires given to 4th-grade students at SDN Ganting, totaling 41 students or respondents. The research was conducted online due to the COVID-19 pandemic. The result of this quantitative research obtained a simultaneous value of 36,227 which was obtained through the ANOVA $F$ test. It can be concluded that the discovery learning model and independent learning influence on student learning outcomes.

Keywords: Discovery Learning Model, Independent Learning, Student Learning Outcomes.

Copyright (c) 2021 Rohmatul Fithriyah, Satrio Wibowo, Rosyidah Umami Octavia

$\triangle$ Corresponding author

Email : rohmatulfitri42@gmail.com

DOI : https://doi.org/10.31004/edukatif.v3i4.894

ISSN 2656-8063 (Media Cetak)

ISSN 2656-8071 (Media Online) 
1908 Pengaruh Model Discovery Learning dan Kemandirian Belajar terhadap Hasil Belajar Siswa di Sekolah Dasar - Rohmatul Fithriyah, Satrio Wibowo, Rosyidah Umami Octavia

DOI: https://doi.org/10.31004/edukatif.v3i4.894

\section{PENDAHULUAN}

Sistem pendidikan serta penerapan pembelajaran yang baik dinilai mampu untuk meningkatkan kualitas dan kuantitas suatu negara. Pendidikan dapat diartikan sebagai suatu usaha sadar yang dilakukan untuk mengembangkan potensi dan keterampilan seseorang. Upaya-upaya untuk mengadakan situasi belajar serta pembelajaran yang efektif dapat dilakukan dengan menyusun suatu program belajar yang memungkinkan siswa untuk mengembangkan potensi dan keterampilan sesuai yang diinginkannya. Undang-Undang No. 20 Tentang Sistem Pendidikan Nasional, mempunyai syarat dalam penerapan sistem pendidikan yaitu: Siswa yang dinilai mampu mengembangkan potensi dan keterampilannya harus memiliki sikap-sikap yang sesuai dengan tujuan pendidikan, yaitu: mempercayai adanya Tuhan, berperilaku yang baik, mampu menjaga kesehatan, mempunyai kemandirian, serta bertanggung. Dapat disimpulkan bahwa sistem pendidikan yang baik mampu mendidik siswa dalam menjadi pribadi yang lebih baik, bertingkah laku sesuai dengan norma, mampu mengembangkan potensi dan ketermpilannya agar berguna baik bagi dirinya sendiri maupun lingkungan masyarakat.

Dalam meningkatkan kualitas pendidikan, guru dapat menyusun suatu program pembelajaran yang efektif bagi siswa. Salah satunya adalah model pembelajaran inkuiri berbasis diskoveri. Pembelajaran diskoveri merupakan suatu susunan kegiatan pembelajaran yang pada penerapannya melibatkan kemampuan peserta didik dalam memperoleh serta mempelajari dengan teratur, mempunyai ketajaman dalam analisis masalah, serta menggunakan pengetahuan yang masuk akal. Dengan hal itu siswa dinilai mampu untuk menemukan secara mandiri kemampuan untuk menemukan pengetahuan yang baru, cara menyikapinya, serta terampil dalam mewujudkan perubahan dari tingkah laku (Hanafiah \& Suhana, 2012).

Model ini berfokus pada penerapan pengalaman langsung pada kegiatan belajar. Selain itu, model discovery juga menitik beratkan pada kemampuan pemahaman peserta didik perihal sesuatu yang dipelajarinya serta mengemukakan ide-ide yang dimilikinya dalam menyelesaikan pembelajaran yang ditempuhnya. Pada pembelajaran discovery, peserta didik langsung menghadapai masalah pokok yang dihadapinya dan berusaha untuk menemukan pengetahuan serta informasi baru melalui pengalaman, sehingga peserta didik mendapatkan pembelajaran yang sarat akan makna dan lebih mudah untuk diingat dan diterapkan dikehidupan sehari-hari.

Pembelajaran discovery mempunyai konsep serta prinsip untuk melibatkan siswa secara langsung dalam pelaksanaan pembelajaran. Hal ini dinilai mampu meningkatkan kemandirian serta hasil belajar siswa. Kemandirian belajar pada siswa memiliki kriteria sebagai berikut, yaitu: percaya diri, sanggup bekerja sendiri, mempunyai rasa tanggung jawab, keinginan untuk maju, disiplin, serta aktif dalam kegiatan pembelajaran (Desmita, 2019). Seorang anak yang mempunyai sikap kemandirian belajar dinilai mampu dalam pembelajaran, aktif, menguasai pembelajaran, serta mampu bertingkah laku yang baik, dan memiliki kepercayaan diri yang tinggi. Kemandirian belajar pada siswa juga dapat diartikan bahwa dalam bersikap mandiri seorang siswa harus memiliki aspek-aspek kemandirian, yaitu: percaya pada kemampuan dirinya sendiri, mampu bekerja sendiri tanpa bantuan orang lain, bertanggung jawab atas apa yang dilakukannya, disiplin dalam mengatur jadwal dan rutinitas, serta aktif dalam pembelaran yang telah diciptakan gurunya di kelas.

Terciptanya kemandirian belajar siswa dinilai mampu dalam meningkatkan hasil belajar karena siswa dianggap telah memahami materi pelajaran secara mandiri. Menurut Sudjana (Sudjana, 2011) hasil belajar siswa merupakan suatu perubahan sikap, pengetahuan, dan keterampilan. Apabila seorang siswa mampu meningkatkan kemandirian belajarnya maka secara tidak langsung siswa tersebut dapat meningkatkan hasil belajar yang dimilikinya. Selain itu, keuntungan yang bisa diambil ketika menerapkan discovery learning adalah kritis dalam segala hal yang dilaluinya, mempunyai kualitas bersosialisasi yang baik, serta bersemangat dalam menemukan hal-hal baru. 
1909 Pengaruh Model Discovery Learning dan Kemandirian Belajar terhadap Hasil Belajar Siswa di Sekolah Dasar - Rohmatul Fithriyah, Satrio Wibowo, Rosyidah Umami Octavia

DOI: https://doi.org/10.31004/edukatif.v3i4.894

Pada masa pandemi covid-19, banyak siswa mengalami penurunan hasil belajar. Hal ini disebabkan ketika siswa menjalani pembelajaran jarak jauh, siswa menjadi kurang aktif dalam mengikuti kegiatan pembelajaran. Terkadang siswa terlalu menyepelekan tugas yang diberikan oleh guru secara online. Pada kegiatan pembelajaran offline, waktu penyampaian materi pelajaran sangat terbatas sehingga pemahaman materi pelajaran oleh siswa kurang.

Alasan peneliti melakukan penelitian yang berjudul "Pengaruh Model Discovery Learning dan Kemandirian Belajar terhadap Hasil Belajar Siswa Kelas 4 SDN Ganting" adalah peneliti ingin mengetahui adanya pengaruh model discovery learning dan kemandirian belajar terhadap hasil belajar siswa kelas 4 SDN Ganting.

\section{METODE PENELITIAN}

Penelitian ini berjenis kuntitatif, dimana data yang diperoleh akan menggunakan angka statistik atau kuantitatif. Populasi serta sampel dalam penelitian ini adalah 41 respoden dari siswa kelas 4 sekolah dasar. Pelaksanaan penelitian dilakukan pada semester genap tahun ajaran 2020/2021, yang bertempat di SDN Ganting, Kecamatan Gedangan, Kabupaten Sidoarjo. Data dikumpulkan melalui teknik observasi dan angket. Observasi dilakukan untuk mengetahui penggunaan model discovery learning pada pembelajaran kurikulum 2013 selama pandemi. Sedangkan angket atau kuisioner digunakan untuk mengetahui adanya pengaruh dari model discovery learning dan kemandirian belajar siswa terhadap hasil belajar siswa. angket yang digunakan adalah angket online menggunakan google form dengan pertimbangan bahwa penelitian dilakukan saat terjadi pandemi covid-19 di Indonesia, dimana pembelajaran lebih banyak dilakukan secara online. Data-data penelitian yang sudah dikumpulkan akan diolah melalui analisis deskriptif. Uji reliabilitas berguna untuk menentukan bahwa instrumen yang digunakan reliabel dan konsisten. Pada intrumen penelitian dengan jumlah 20 soal pernyataan yang digunakan menunjukkan hasil yang reliabel karena nilai alpha cronbach $=0,939$, dengan ketentuan $\left(\mathrm{r}_{11}\right)>0,6$. Uji koefisensi menggunakan korelasi berganda berfungsi untuk mencari hubungan variabel $X_{1}, X_{2}$ secara bersama-sama dengan variabel $Y$. Validitas data diukur menggunakan ketentuan $t_{\text {hitung }}>t$ tabel signifikan $(a=0,05)$ dan Ha diterima atau hipotesis diterima dan menunjukkan adanya pengaruh dari variabel $\mathrm{X}$ dan Y. Sedangkan jika terjadi sebaliknya, yakni $\mathrm{t}_{\text {hitung }}<\mathrm{t}_{\text {tabel }}$, maka tidak signifikan atau $\mathrm{H}_{0}$ diterima, dengan artian tidak ada pengaruh antara ketiga variabel.

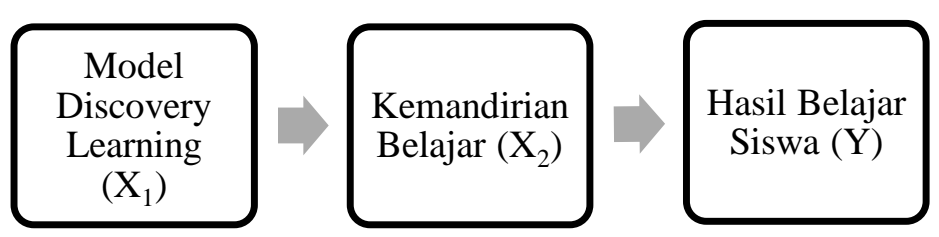

Gambar 1. Desain Penelitian

\section{HASIL DAN PEMBAHASAN PENELITIAN}

Penelitian ini menggunakan acuan rencana pelaksanaan pembelajaran (RPP) daring tema 9 kayanya negeriku, subtema 1 kekayaan sumber energi di Indonesia, dan pembelajaran ke-1. Alokasi waktu pada setiap pembelajaran adalah 6 × 35 menit. 
1910 Pengaruh Model Discovery Learning dan Kemandirian Belajar terhadap Hasil Belajar Siswa di Sekolah Dasar - Rohmatul Fithriyah, Satrio Wibowo, Rosyidah Umami Octavia

DOI: https://doi.org/10.31004/edukatif.v3i4.894
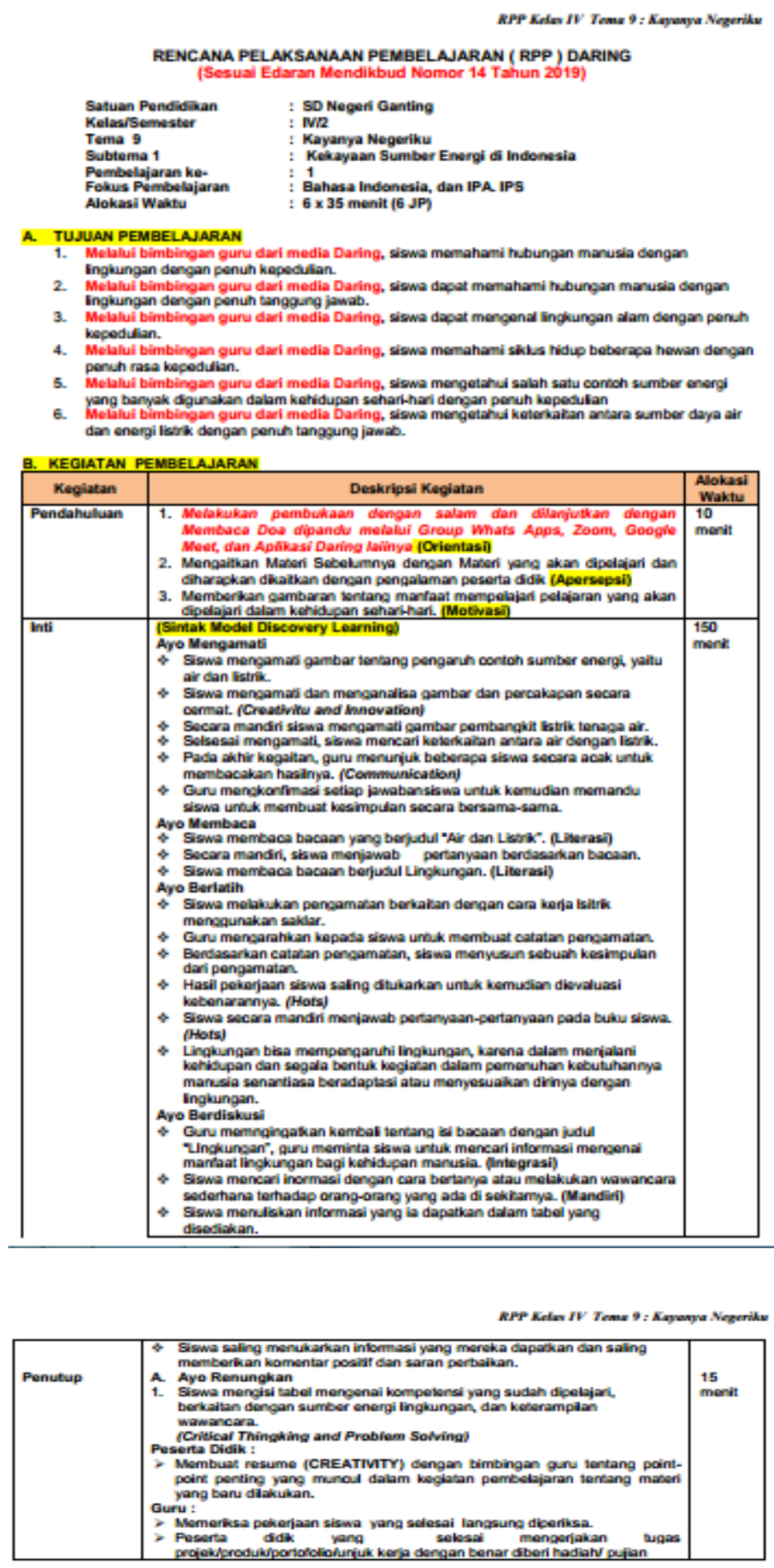

c. Penilalan (asesmen)

Penllaian tertadap materi in dapat Gilakukan sesuai kebusuhan gun yaltu dari pengamatan skap, ses pengetahuan dan presentasi unyjuk kerja atau hesil karyarprojek dengan nubric perilaian.
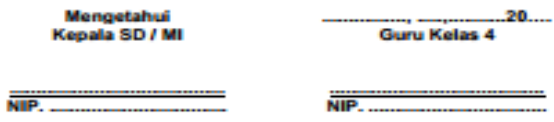

Gambar 2. RPP Daring Tema 9, Subtema 1, kelas 4 Sekolah Dasar 
1911 Pengaruh Model Discovery Learning dan Kemandirian Belajar terhadap Hasil Belajar Siswa di Sekolah Dasar - Rohmatul Fithriyah, Satrio Wibowo, Rosyidah Umami Octavia

DOI: https://doi.org/10.31004/edukatif.v3i4.894

\section{Rata-Rata Skor Variabel}

Data yang diperoleh dari google form akan diunduh dalam bentuk data microsoft excel yang kemudian akan dikelola melalui bantuan aplikasi SPSS 24.00 for windows. berikut hasil dari pengolahan data.

Tabel 1. Hasil skor analisis deskriptif

\begin{tabular}{llll}
\hline Variabel & $\mathbf{X}_{\mathbf{1}}$ & $\mathbf{X}_{\mathbf{2}}$ & $\mathbf{Y}$ \\
\hline $\mathrm{N}$ & 41 & 41 & 41 \\
\hline Mean & 54,49 & 56,49 & 61,61 \\
\hline Median & 53 & 56 & 59 \\
\hline Standar deviasi & 8,572 & 7,684 & 8,186 \\
\hline
\end{tabular}

Pengaruh model discovery learning menunjukkan nilai rata-rata 54,49 yang menunjukkan bahwa penerapan pembelajaran diskoveri pada sekolah dasar berkategori sedang. Artinya hampir semua siswa memiliki indikator diskoveri yakni: 1) peserta didik terlibat aktif dalam proses pembelajaran, 2) peserta didik dapat berfikir logis, analisis, serta kritis, 3) peserta didik mengurangi sikap ketergantungan kepada guru, 4) peserta didik memanfaatkan lingkungan sebagai tempat belajar (Habibu \& Eca, 2019). Demikian juga dengan nilai rata-rata kemandirian belajar mendapatkan skor 56,49 dengan kategori sedang. Dapat diartikan bahwa siswa kelas 4 SDN Ganting sudah memiliki kemandirian dalam aktivitas belajarnya. Kemandirian belajar mempunyai tujuh indikator pencapaian yaitu: percaya pada diri sendiri, mempunyai kemampuan untuk bekerja sendiri, mampu mengambil keputusan, dapat bertanggung jawab pada dirinya sendiri, mempunyai keiinginan untuk bersaing maju, disiplin dalam mengatur waktu, serta aktif dalam kegiatan pembelajaran (Tresnaningsih et al., 2019). Sedangkan pada hasil belajar siswa menunjukkan skor 61,61 dengan kategori tinggi. Hasil belajar siswa yang digunakan sebagai objek penilaian diperoleh dari pencapaian siswa terhadap indikator-indikator sebagai berikut: 1) siswa dapat mengidentifikasi sumber energi dan pemanfaatannya, 2) siswa dapat menggali informasi melalui wawancara, 3) siswa dapat menyajikan hasil dari indentifikasi dan melaporkan hasil wawancara.

\section{Uji Validitas Data Variabel}

Uji normalitas digunakan untuk mengetahui data yang diolah terdistribusi normal atau tidak. Selanjutnya akan dilakukan uji korelasi berganda untuk menghitung tingkat hubungan dari ketiga variabel secara bersama-sama.

Tabel 2. Uji normalitas

\begin{tabular}{lllll}
\hline \multicolumn{2}{c}{ Normality Test } & \multicolumn{3}{c}{ Correlation Test } \\
\hline Std. Deviation & Asymp. Sig & $R$ & R. Square & Sig. F Change \\
\hline 4,507 & 0,200 & 0,810 & 0,656 & 0,000 \\
\hline
\end{tabular}

Hasil dari Uji normalitas mempunyai hasil sebaran data berdistribusi normal. Penyebaran data menggunakan teknik kolmogorov smirnov dengan signifikan sebesar 0,200 > dari probabilitas signifikan sebesar 0,05. Hasil uji korelasi berganda menunjukkan bahwa tingkat hubungan antara model discovery learning dan kemandirian belajar (simultan) terhadap hasil belajar siswa yang dihitung secara bersama-sama dan menunjukkan koefisien korelasi sebesar 0,810, yang berarti tingkat hubungan adalah sangat tinggi. Tingkat hubungan korelasi dapat diketahui melalui tabel di bawah ini.

Tabel 3. Tingkat Hubungan Koefisien Korelasi

\begin{tabular}{cc}
\hline Interval koefisien & Tingkat hubungan \\
\hline $0,00-0,199$ & Sangat rendah \\
\hline
\end{tabular}


1912 Pengaruh Model Discovery Learning dan Kemandirian Belajar terhadap Hasil Belajar Siswa di Sekolah Dasar - Rohmatul Fithriyah, Satrio Wibowo, Rosyidah Umami Octavia

DOI: https://doi.org/10.31004/edukatif.v3i4.894

\begin{tabular}{cc}
\hline $0,20-0,399$ & Rendah \\
\hline $0,40-0,599$ & Sedang \\
\hline $0,60-0,799$ & Kuat \\
\hline $0,80-1,000$ & Sangat kuat \\
\hline
\end{tabular}

(Sugiyono, 2018)

Dari tabel 2 dapat diketahui bahwa kontribusi variabel model discovery learning dan kemandirian belajar terhadap hasil belajar siswa adalah 65,6\%, sedangkan 34,4\% dipengaruhi oleh faktor di luar variabel.

Selanjutnya dilakukan uji t (parsial) untuk menguji hipotesis dari korelasi product moment. Pengujian hipotesis secara parsial menunjukkan hasil sebagai berikut: 1) uji pertama, dilakukan untuk mengetahui pengaruh model discovery learning terhadap hasil belajar, diperoleh nilai $t_{\text {hitung }}=2,721>t_{\text {tabel }}=2,024,2$ ) $u j i$ kedua, dilakukan untuk mengetahui adanya pengaruh dari kemandirian belajar dengan hasil belajar siswa, memperoleh harga $t_{\text {hitung }}=0,344<t_{\text {tabel }}=2,024$.

Tabel 4. Uji Hipotesis t (Parsial)

\begin{tabular}{ccc}
\hline Variabel & t & Sig. \\
\hline $\mathrm{Y}$ & 4,069 & 0,000 \\
\hline $\mathrm{X}_{1}$ & 2,721 & 0,010 \\
\hline $\mathrm{X}_{2}$ & 0,344 & 0,733 \\
\hline
\end{tabular}

Dari tabel tersebut dapat diketahui bahwa harga t dari variabel model discovery learning terhadap hasil belajar siswa memperoleh nilai sebesar 2,721 lebih besar dari 2, 024, yang berarti bahwa model pembelajaran diskoveri mempunyai pengaruh pada hasil belajar siswa. Sedangkan kemandirian belajar memperoleh nilai $t$ sebanyak 0,344 yang menunjukkan bahwa kemandirian belajar kurang berpengaruh pada hasil belajar siswa. Untuk mengetahui pengaruh model discovery learning dan kemandirian belajar, terhadap hasil belajar secara simultan (gabungan) digunakan uji $\mathrm{F}$ ANOVA, diperoleh hasil data nilai signifikan $<$ dari 0,05 , yaitu 0,00 konstan dan $\mathrm{F}_{\text {hitung }}=36,227>\mathrm{F}_{\text {tabel }}=3,24$.

Tabel 5. Uji Hipotesis F Simultan

\begin{tabular}{cccc}
\hline Model & df & F & Sig \\
\hline Regression & 2 & 36,227 & 0,000 \\
\hline residual & 38 & & \\
\hline
\end{tabular}

Berdasarkan hasil dari penelitian yang sudah dilakukan, model discovery learning dan kemandirian belajar mempunyai pengaruh yang cukup signifikan terhadap hasil belajar siswa. kesesuaian data tersebut mempunyai korelasi dengan pernyataan dari Priansa (dalam Habibu \& Eca, 2019) bahwa pembelajaran diskoveri dapat mendorong peserta didik untuk lebih responsif terhadap hal-hal baru dan dapat menarik kesimpulan dari sesuatu yang dipelajarinya. Selain itu dengan pembelajaran diskoveri guru hanya sebagai fasilitator dalam kegiatan pembelajaran. Seorang guru harus menciptakan pembelajaran semenarik mungkin untuk mendorong stimulus siswa agar berpikir aktif dalam kegiatan pembelajaran. Kegiatan pembelajaran discovery juga merangsang kemandirian belajar siswa, dimana siswa akan berpikir lebih aktif, kreatif, bertanggung jawab pada tugas-tugasnya. Kemandirian merupakan suatu tindakan melepaskan diri dari orang tua serta proses pencarian jati diri (Desmita, 2019). Hal ini ditandai dengan seorang anak mampu menentukan nasibnya sendiri, dapat berpikir kreatif dan inovatif, dapat mengatur pola tingkah laku, bertanggung jawa terhadap apa yang dilakukannya, mampu mengontrol emosi, serta mampu membuat keputusan secara mandiri. Seorang siswa yang memiliki kemandirian belajar dinilai mampu memiliki hasil belajar yang baik. Alasannya adalah siswa tersebut dinilai mampu untuk mengendalikan emosi serta kebiasaan-kebiasaan kurang baik 
1913 Pengaruh Model Discovery Learning dan Kemandirian Belajar terhadap Hasil Belajar Siswa di Sekolah Dasar - Rohmatul Fithriyah, Satrio Wibowo, Rosyidah Umami Octavia

DOI: https://doi.org/10.31004/edukatif.v3i4.894

dalam belajar. Kebiasaan-kebiasaan kurang baik tersebut meliputi : ketergantungan kepada orang lain, sikap apatis, dan kecenderungan berpikir tidak jujur.

Hasil belajar siswa dapat dipengaruhi oleh model pembelajaran di kelas yang diterapkan oleh guru, serta kemandirian belajar siswa tersebut. Penggunaan model, pembelajaran diskoveri dinilai dapat memicu kemandirian belajar siswa yang mempunyai dampak pada peningkatan hasil belajar siswa. Penerapan model discovery learning juga bermanfaat bagi guru karena selain menjadi fasilitator dalam pembelajaran, seorang guru juga dapat memahami karakteristik belajar dari siswa-siswanya. Berdasarkan hasil uraian dari data-data penelitian, diketahui bahwa model discovery learning dan kemandirian belajar mempunyai pengaruh pada hasil belajar siswa, serta dinilai lebih efektif dalam merangsang siswa agar lebih aktif dalam kegiatan belajarnya.

\section{KESIMPULAN}

Kesimpulan yang dapat ditarik dari hasil analisis serta pembahasan dari penelitian adalah, Pertama, pembelajaran yang menerapkan discovery learning memperoleh nilai t sebesar 2,721 yang mana lebih besar dari 2,024. Nilai rata-rata pembelajaran yang menerapkan discovery learning termasuk dalam kategori sedang, yaitu 54,49. Discovery learning juga dinilai lebih efektif ketika diterapkan pada situasi pandemi covid-19 karena akan memberikan stimulus untuk siswa agar lebih bersikap mandiri dan aktif dalam kegiatan pembelajaran.

Kedua, kemandirian belajar siswa semasa pandemi covid-19 dinilai kurang. Hal ini bisa dilihat dari perolehan nilai rata-rata sebanyak 56,49 dengan kategori sedang dan harga t hitung yang kurang dari t tabel, yaitu: $0,344<2,024$. Ketiga, hasil dari uji $\mathrm{F}$ simultan menunjukkan perbedaan dari uji t secara parsial. Nilai uji $\mathrm{F}$ berdasarkan signifikasi diketahui sebanyak 0,000 konstan serta nilai $\mathrm{F}$ hitung $=36,227$ lebih besar daripada $\mathrm{F}$ tabel $=3,24$, yang berarti hipotesis diterima dan model discovery learning serta kemandirian belajar mempengaruhi hasil belajar siswa.

Saran peneliti dalam penelitian ini adalah peningkatan kualitas pembelajaran khususnya ketika terjadi pandemi covid-19 yaitu yang pertama adalah, guru dituntut agar lebih kreatif dalam menyajikan pembelajaran supaya siswa tidak bosan dan kehilangan semangat belajarnya. Kedua, pengawasan dari orang tua sangat perlu ketika pembelajaran jarak jauh berlangsung, karena siswa dapat mengakses berbagai situs dari internet ketika pembelajaran online berlangsung. Ketiga, pada pengambil kebijkan, khusunya menteri pendidikan untuk menciptakan model-model pembelajaran yang dinilai sesuai ketika diterapkan di sekolah selama pandemi berlangsung. Keempat, kepada peneliti lain yang mempunyai minat dalam meneliti model discovery learning dapat diharapkan untuk melanjutkan penelitian dengan berbagai variabel inovatif lainnya supaya suasana pendidikan di Indonesia dapat berbenah menjadi lebih baik.

\section{UCAPAN TERIMA KASIH}

Ucapan terima kasih peneliti persembahkan kepada Allah SWT, kedua orang tua peneliti, dosen-dosen yang membimbing, dan teman-teman peneliti.

\section{DAFTAR PUSTAKA}

Astari, F. A., Suroso, S., \& Yustinus, Y. (2018). Efektifitas Penggunaan Model Discovery Learning Dan Model Problem Based Learning Terhadap Hasil Belajar IPA Siswa Kelas 3 SD. Jurnal Basicedu, 2(1), 1-10. Https://Doi.Org/10.31004/Basicedu.V2i1.20

Desmita, D. (2009). Psikologi Perkembangan Peserta Didik. Bandung : PT Remaja Rosdakarya. 
1914 Pengaruh Model Discovery Learning dan Kemandirian Belajar terhadap Hasil Belajar Siswa di Sekolah Dasar - Rohmatul Fithriyah, Satrio Wibowo, Rosyidah Umami Octavia

DOI: https://doi.org/10.31004/edukatif.v3i4.894

Desyandri, D., Muhammadi, M., Mansurdin, M., \& Fahmi, R. (2019). Development Of Integrated Thematic Teaching Material Used Discovery Learning Model In Grade V Elementary School. Jurnal Konseling Dan Pendidikan, 7(1), 16. Https://Doi.Org/10.29210/129400

Dewi, W. A. F. (2020). Dampak Covid-19 Terhadap Implementasi Pembelajaran Daring Di Sekolah Dasar. Edukatif: Jurnal Ilmu Pendidikan, 2(1), 55-61.

Fauzi, M. (2020). Strategi Pembelajaran Masa Pandemi COVID-19. Jurnal Al-Ibrah, 2(2), 120-145. Retrieved From Https://Ejournal.Stital.Ac.Id./Index.Php/Alibrah/Article/View/104/88

Habibu, R., \& Eca, M. G. (2019). Model-Model Pembelajaran Anak Usia Dini. Yogyakarta: Ar-Ruzz Media.

Hamalik, O. (2013). Proses Belajar Mengajar. Jakarta: PT Bumi Aksara

Hamdani, A. R., \& Priatna, A. (2020). Efektifitas Implementasi Pembelajaran Daring (Full Online) Dimasa Pandemi Covid-19 Pada Jenjang Sekolah Dasar Di Kabupaten Subang. Didaktik: Jurnal Ilmiah PGSD STKIP Subang, 6(1), 1-9.

Hanafiah, N., \& Suhana, C. (2012). Konsep Strategi Pembelajaran. Bandung: Refika Aditama.

Hayati, I. S. W., Manzilatusifa, U., \& Handoko, S. (2017). Pengaruh Penerapan Model Discovery Learning Terhadap Kemandirian Belajar Siswa. Jurnal Pendidikan Dan Pembelajaran Ekonomi Akuntansi, 3(1).

Octavia, R. U. (2020). Upaya Melatih Kemandirian Belajar Melalui Outdoor Learning (ODL) Siswa Kelas III SDN Pucang 4 Sidoarjo. Mubtadi: Jurnal Pendidikan Ibtidaiyah, 2(1), 59-64.

Rahmawati, Desi. (2016). Hubungan Antara Kemandirian Belajar Dengan Hasil Belajar Siswa SD Negeri Purwoyoso 06 Semarang. Skripsi, 15-26.

Rusman. (2013). Model-Model Pembelajaran. Jakarta: PT Raja Grafindo Persada.

Sa'diyah, R. (2017). Pentingnya Melatih Kemandirian Anak. Kordinat: Jurnal Komunikasi Antar Perguruan Tinggi Agama Islam, 16(1), 31-46.

Sudjana, N. (2011). Penilaian Hasil Proses Belajar Mengajar. Bandung: PT Remaja Rosdakarya.

Sugiyono. (2018). Metode Penelitian Kuantitatif, Kualitatif, Dan R\&D. Bandung: PT Alfabeta.

Sugiyono. (2019). Metode Penelitian Pendidikan. Bandung: PT Alfabeta.

Suprijono, A. (2020). Kesiapan Dunia Pendidikan Menghadapi Era New Normal. Parepare: IAIN Parepare Nusantara Press.

Tresnaningsih, F., Santi, D. P. D., \& Suminarsih, E. (2019). Kemandirian Belajar Siswa Kelas Iii Sdn Karang Jalak I Dalam Pembelajaran Tematik. Pedagogi: Jurnal Penelitian Pendidikan, 6(2), 51-59. Https://Doi.Org/10.25134/Pedagogi.V6i2.2407

Undang-Undang, R. I. (2013). No. 20 Tahun 2013 Tentang Sistem Pendidikan Nasional. Bandung: Citra Umbara.

Yulianingsih, W., Suhanadji, S., Nugroho, R., \& Mustakim, M. (2020). Keterlibatan Orangtua Dalam Pendampingan Belajar Anak Selama Masa Pandemi Covid-19. Jurnal Obsesi : Jurnal Pendidikan Anak Usia Dini, 5(2), 1138-1150. Https://Doi.Org/10.31004/Obsesi.V5i2.740 